REPORTS OF MORPHOLOGY
Official Journal of the Scientific Society of Anatomists,
Histologists, Embryologists and Topographic Anatomists
of Ukraine
journal homepage: https://morphology-journal.com

\title{
INDICATORS OF CARDIOVASCULAR SYSTEM IN PERSONS OF MATURE AGE DEPENDING ON ABODY CONSTITUTION UNDER ADVERSE ECOLOGICAL CONDITIONS
}

\author{
Shevchuk T.Ya. ${ }^{1}$, Pshybelskyj V.V. ${ }^{2}$, Zhuravlov O.A. ${ }^{1}$, Zhuravlova O.V. $^{1}$ \\ ${ }^{1}$ Lesya Ukrainka East European National University, Lutsk, Ukraine
} ${ }^{2}$ Volyn Regional Ecological and Naturalistic Center, Lutsk, Ukraine

\section{ARTICLE INFO}

Received: 18 December, 2020

Accepted: 20 January 2021

UDC: [572.784:572.783]-

053.85(043.5)

\section{CORRESPONDING AUTHOR}

e-mail: tetyana_shevchuk_2013@ukr.net Shevchuk T.Ya.

\begin{abstract}
Human health and its optimal functional state depend on the efficiency of the body's regulatory systems that respond to changes in a complex of exogenous and endogenous factors, ensuring timely adaptation to changing living conditions. However, natural factors, which largely determined the direction of evolution of the human body, are increasingly receding into the background, giving way to anthropogenic factors, including working conditions. That is why the aim of the scientific article was to study the state of the cardio-respiratory system in workers who are involved in various production processes, depending on their body constitution. The study of central and cerebral hemodynamics was conducted on men aged 21-35 years (90 people in total), which were divided into 3 groups, 30 persons in each: involved in industrial production, agricultural workers and residents of relatively environmentally friendly areas of Volyn region. At the first stage of the study, absolute anthropometric indicators (age, height, weight, chest circumference) were measured and the integrated indicator (Pignet index) was calculated. The next stage of the study involved functional diagnostics of the cardiovascular system of the subjects using functional ECG techniques, Kubicek rheography and rheoencephalography. Registration and analysis of relevant indicators was carried out using a set of hardware and software survey methods "Askold" (Kyiv, 1997). Statistical analysis of intergroup differences was performed using Student's $t$ test and Man-Whitney U-test, the level of relationship between the individual parameters was assessed by the Pearson method. It is proved that the anthropometric indicators of persons exposed to chronic exposure to harmful production factors do not differ in the group of persons involved in industrial production and in agriculture. It is shown that in subjects who are exposed to negative factors of the production environment for a long time (both during the production of agricultural products and in an industrial enterprise) there are compensatory changes in central hemodynamics (stroke volume and myocardial capacity) compared with the control group persons from ecologically clean areas of Volyn region. Employees of the industrial enterprise showed signs of deterioration of the amplitude-time characteristics of cerebral blood flow in both hemispheres, as evidenced by indicators of rapid filling time, rheographic coefficient and average blood flow velocity. These parameters differ from similar parameters of agricultural workers and residents of relatively environmentally friendly regions. Thus, the identified features of the indicators in the groups of subjects exposed to chronic exposure to negative factors of the production environment, indicate the functional nature of the identified changes that are compensatory in nature.

Keywords: factors of the production environment, central hemodynamics, cerebral hemodynamics, ECG, anthropometric indicators.
\end{abstract}

\section{Introduction}

The role of environmental factors complex in the system of formation and modification of regulatory reactions of the organism is generally accepted, but the constant development of technologies and materials significantly affects the anatomical and physiological features of the human body $[3,9,10,14]$. The widest range of such effects 
is found in industrial production, which poses a very important task - monitoring and timely response to the emergence of "new" harmful factors of the production environment and analysis of their possible combined impact on human health [1, 11, 15, 22, 24].

It should be noted that, on the other hand, the peculiarities of the response of body systems to the action of environmental factors are determined by their own (individual) predictors. Factors that modify the impact of negative environmental factors are age, sex, health status, diet, stress resistance, the constitution of the worker's body and others [15, 16, 21, 23].

Thus, a comprehensive analysis of the studied problem on the one hand should include the study of the peculiarities of working conditions and, on the other hand, the characteristics of the workers involved in it $[11,13,17]$. That is why the purpose of scientific research was to study the state of the cardio-respiratory system in workers who are involved in various production processes, depending on their body constitution.

\section{Materials and methods}

Studies of central and cerebral hemodynamics were performed on men aged 21-35 years. The total number of subjects was 90 people, and, according to the purpose of the work, they were divided into three groups 30 people each, namely: control - the population living in a relatively clean ecological zone (Kivertsi region); agrarian sector residents of agrarian districts of Volyn region, who are engaged in agriculture and are in constant contact with fertilizers and pesticides (Ivanychi and Lokachi); industry subjects who work at industrial enterprises in the city of Lutsk. All subjects were informed about the features of the experiment and gave their consent to its conduct and processing of the results.

At the first stage of the study we performed anthropometric measurements of height, body weight and chest girth, which were performed according to the method of Bunak (1931) [7] and calculated the Pignet index (PI), which characterizes the proportionality of development and physique [18, 21]:

$\mathrm{IP}=\mathrm{L}-(\mathrm{M}+\mathrm{O})$,

where $L$ - height, $\mathrm{cm}$;

$\mathrm{M}$ - mass, kg;

$\mathrm{O}$ - chest circumference, $\mathrm{cm}$.

To determine the type of body constitution used the classification of V.M. Chernorutsky (1927) which provides for the allocation of three categories: hyposthenics (PI>30 conventional units), normosthenics (PI 1-30 conventional units) and hypersthenics (PI<10 conventional units) [18].

The next stage of the study involved functional diagnostics of the cardiovascular system of the subjects using the ECG method, Kubicek rheography and rheoencephalography. The registration and analysis of the relevant indicators was carried out with the help of the "Askold" software and hardware complex (Kyiv, 1997).
The obtained data were processed using parametric and nonparametric methods: Student's criterion $(t)$ when comparing averages and Mana-Whitney (U) when comparing medians. Correlation analysis of the obtained data was performed according to Pearson's test. SPSS 23.0 software was used for statistical analysis of the obtained results.

\section{Results}

Anthropometric indicators of workers involved in industrial and agricultural production and exposed to the constant influence of negative environmental factors, generally do not differ between the studied groups. However, the weight of the studied control group was significantly $(p<0.05)$ higher than in both groups involved in production. The body weight of workers in the agroindustrial complex was significantly lower than the body weight of the control group, and a similar figure for employees of industrial enterprises (Table 1).

Significant differences between the comparison groups according to the Pignet index were noted only when comparing groups from ecologically clean areas of Volyn region and agricultural workers, and higher values were noted in the latter.

The use of the Pignet index made it possible to establish certain features of the ratio of different body types of the studied contingent. In particular, it was found that among the three studied groups the predominant is the normosthenic type of physique, which was found in half of the subjects of the control group and in employees of industrial enterprises, as well as in $71 \%$ of workers in the agro-industrial complex. It should be noted that in the persons involved in agro-industrial enterprises, no persons with hypertensive body type were found, while in both other groups their number was $26 \%$ and $30 \%$.

Modern scientific research aims to conduct a comprehensive analysis of the impact of environmental factors on the human body due to their constant deterioration. Functional reserves of the human body are increasingly strained, and regulatory systems that maintain homeostasis, show signs of dysfunction, accompanied by

Table 1. Anthropometric indicators of persons studied groups, selected taking into account complex of environmental factors $(\mathrm{M} \pm \sigma)$.

\begin{tabular}{|l|c|c|c|}
\hline \multicolumn{1}{|c|}{ Indexes } & Control group & Industry & $\begin{array}{c}\text { Agricultural } \\
\text { sector }\end{array}$ \\
\hline Height, $\mathrm{cm}$ & $178,3 \pm 5,2$ & $179,3 \pm 7,6$ & $177,9 \pm 4,8$ \\
\hline Weight, $\mathrm{kg}$ & $76,65 \pm 6,12$ & $73,13 \pm 10,11^{*}$ & $67,08 \pm 5,60^{\star, * *}$ \\
\hline $\begin{array}{l}\text { Chest circumference, } \\
\mathrm{cm}\end{array}$ & $85,10 \pm 8,65$ & $83,91 \pm 9,84$ & $82,75 \pm 4,33^{*}$ \\
\hline Age, years & $26,40 \pm 3,66$ & $26,61 \pm 4,14$ & $25,63 \pm 3,85$ \\
\hline Pignet index & $16,55 \pm 11,02$ & $22,26 \pm 14,54$ & $28,08 \pm 8,72^{*}$ \\
\hline
\end{tabular}

Notes: * - statistically significant difference of indicators compared with the control group; ** - statistically significant difference between the groups of persons involved in agricultural production and industry. 
depletion of adaptive reserves and can lead to the development of pathological conditions [2, 16]. An important aspect of this problem is the mandatory consideration of the constitutional features of man, because to a large extent they determine the "initial" state of the adaptive capabilities of the human body [21].

Our analysis of the main intervals according to the ECG at rest showed that the RR interval in the subjects involved in agricultural production was statistically significantly $(p<0.05)$ greater than in the studied workers of industrial enterprises in persons with hyposthenics body type $(0.97 \pm 0.28 \mathrm{~s}$ and $0.72 \pm 0.15 \mathrm{~s}$, respectively), while in normosthenics there is an inverse relationship: higher values are observed in persons involved in industrial production $(0.86 \pm 0.15 \mathrm{~s}$ and $0.97 \pm 0.12 \mathrm{~s}$, respectively). At the same time, there are no significant intergroup differences between these groups compared to the control group.

The duration of the $P Q$ interval in the subgroup of hyposthenics did not show a significant difference in values between the main comparison groups. In persons involved in industrial production with hypersthenic body type there is a significant $(p<0.05)$ lengthening of the interval compared with the control group. Subjects with normosthenic type of physique are characterized by a significant $(p<0.05)$ increase in the $P Q$ interval in workers of the agro-industrial complex when comparing similar parameters of the inhabitants of relatively ecologically clean areas.

The values of the QT segment of the electrocardiogram in the studied with different ratios of harmful production factors revealed statistically significant $(p<0.05)$ differences in the groups of hyposthenics and normosthenics, selected on the basis of the Pignet index, while hypersthenics did not show significantly significant intergroup differences in QT interval (Fig. 1).

Thus, in particular, in the group of hyposthenics there is a significantly $(p<0.05)$ shorter QT interval in persons involved in industrial production, compared with workers in the agricultural sector. In normosthenics, statistically significant $(p<0.05)$ differences in the duration of the QT interval were observed when comparing the latter with the inhabitants of relatively environmentally friendly regions.

Analysis of the QRS interval showed that regardless of the type of physique, the difference in values between the comparison groups does not reach the level of statistically significant, and the values range from 0.07 to $0.09 \mathrm{~s}$.

The study of central hemodynamics has revealed a number of features in people with different body types under conditions of chronic exposure to harmful production factors. The stroke volume of blood, which characterizes the strength and efficiency of heart rate, and its minute volume show statistically significant $(p<0.05)$ differences in both groups of subjects involved in production, compared with the control group, both in normosthenics and hypersthenics. In individuals with hyposthenic physique, intergroup differences were not detected by any of the

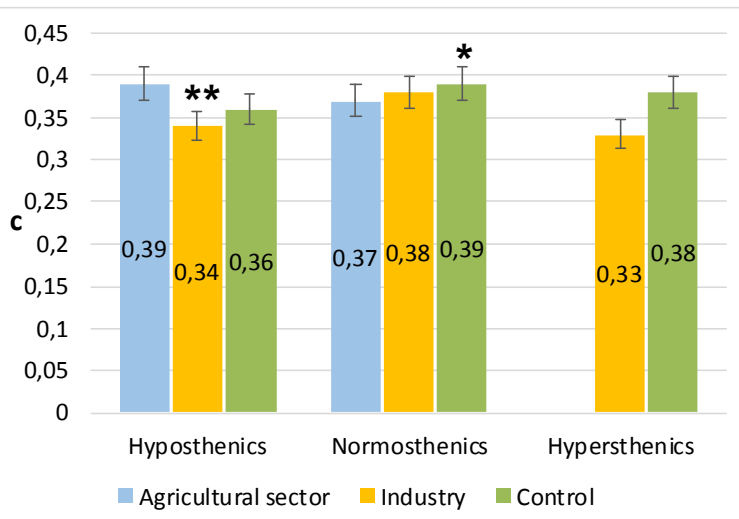

Fig. 1. Indicators of QT interval duration in subjects exposed to chronic environmental factors depending on body type. * statistically significant difference of indicators compared with the control group; ${ }^{* *}$ - statistically significant difference between the groups of persons involved in agricultural production and industry.

\section{indicators.}

The volumetric emission rate did not reveal a significant difference in values between the comparison groups on the characteristics of the environmental impact of harmful production factors, selected taking into account the Pinier index, and its values ranged from 0.21 to $0.27 \mathrm{ml} / \mathrm{s}$.

Myocardial power values are characterized by a statistically significant $(p<0.05)$ difference between the two studied groups of persons (involved in industrial production and the agricultural sector) and residents of a relatively clean area only in the group of normosthenics. No significant intergroup differences were found in subjects with hypo- and hypersthenic body constitution.

As in the analysis of the previous indicator, the values of mean dynamic pressure and myocardial energy expenditure are characterized by the presence of significant $(p<0.05)$ differences only in the group of normosthenics. In particular, it is shown that the studied parameter is higher in the group of persons involved in the agrarian sector, compared with the control group. No statistically significant intergroup differences were found in the subjects of hypersthenic and hyposthenic body type.

Thus, the study of central blood flow and electrical activity of the myocardium when dividing the study into groups by body type made it possible to identify a significant number of differences between the studied indicators in groups with different types of production conditions: the largest number of intergroup differences is observed in hypersthenics (stroke and minute blood volumes, stroke and cardiac indices, as well as a decrease in peripheral resistance), while in other groups there are significant differences. According to the ECG data, a significant difference was found between the values of the RR interval in the subjects with hypo- and normosthenic body constitution when comparing groups from the agricultural and industrial sectors. In hypersthenics, there was a difference between the duration of the $P Q$ interval between 
the control group and workers involved in industrial production.

The next stage of the study was to determine the level of the relationship between the parameters of central hemodynamics and the Pignet index in the studied groups of individuals, selected by the characteristics of the impact of harmful factors of the working environment. The analysis showed that the highest level of correlation was observed in the control group, while the number of workers and agroindustrial complexes and the level of identified relationships were much lower. The highest values of the correlation coefficient were observed for the indicators of the minute volume of blood flow $(r=0.49)$, cardiac index $(r=0.47)$ and total peripheral resistance $(r=-0.41)$, while the other indicators are characterized by the level of correlation in the range of $31-34 \%$.

Under conditions of long-term exposure to harmful environmental factors, changes in blood flow are primarily found in medium and small vessels, which is reflected in reduced regional blood flow, changes in vascular tone and dysregulatory effects, which are observed by some scientists [12, 25].

The analysis of the main parameters of REG in groups selected on the basis of the Pignet index showed that in subjects with hyposthenic type there are statistically significant $(p<0.05)$ higher values of pulse blood supply in both hemispheres in subjects involved in agro-industrial production, compared to with the control group and with industry workers.

In hypersthenics during the experiment there was no significant difference of Period of Pulse Blood Supply values between the comparison groups, while in normosthenics intergroup differences were found in different hemispheres: in the right marked significantly $(p<0.05)$ higher values in the group of persons involved in agricultural production $(0.76 \pm 0.10 \mathrm{~s})$ compared with the control group $(0.87 \pm 0.06$ $s)$, and in the left - lower $(p<0.05)$ values $(0.76 \pm 0.10 \mathrm{~s})$, compared with the group of persons from industrial enterprises $(0.88 \pm 0.27 \mathrm{~s})$.

Analysis of the values of the time of rapid filling of the vessels of the brain, taking into account the type of physique of the subjects showed that in the group of hyposthenics there are statistically significant $(p<0.05)$ lower values in both hemispheres compared with those involved in industrial $(0.04 \pm 0.01 \mathrm{~s}$ on the left and $0.05 \pm 0.01 \mathrm{~s}$ on the right) and agricultural $(0.06 \pm 0.02 \mathrm{~s}$ on the left and $0.06 \pm 0.01$ $s$ on the right) productions.

In the group with normosthenic body type, industrial persons were characterized by significantly $(p<0.05)$ lower values of rapid filling time compared with the group involved in agricultural production, and with a group of residents of relatively clean areas of Volyn region (in the right hemisphere $0.03 \pm 0.01 \mathrm{~s}$ versus $0.05 \pm 0.01 \mathrm{~s}$ and $0.06 \pm 0.01$ $\mathrm{s}$, respectively). In the left hemisphere, statistically significant $(p<0.05)$ lower values of the fast filling time were observed in employees of industrial enterprises only in comparison with similar indicators of the control group.

In hypersthenics, the values of the fast filling time differ $(p<0.05)$ only in the left hemisphere when comparing the indicators of those studied in industrial production and the control group $(0.05 \pm 0.01 \mathrm{~s}$ and $0.08 \pm 0.02 \mathrm{~s}$, respectively).

The values of the maximum filling time in absolute terms were higher in the subjects involved in industrial and agricultural production. It should be noted that the level of significantly significant $(p<0.05)$ they reached only in the right hemisphere when comparing the control group and employees of industrial enterprises of persons with hypersthenic body type.

The value of the latency delay time, which characterizes the peculiarities of blood flow along the main vessels of the brachiocephalic trunk, taking into account the physique of the subjects did not reveal significantly significant differences between the comparison groups. All values were distributed within $0.14-0.17 \mathrm{~s}$ and were within normal limits. The only intergroup difference of the indicator is observed in the right hemisphere in the group of normosthenics: significantly higher $(p<0.05)$ values occur in the studied industrial enterprises, compared with the control group of individuals.

The rheographic index of the subjects was characterized by an inhomogeneous distribution of values among the comparison groups: in the group of hypersthenics involved in industrial production, there were significantly higher $(p<0.05)$ values in the right hemisphere $(0.09 \pm 0.01 \mathrm{Ohm})$, compared with the left $(0.07 \pm 0.02 \mathrm{Ohm})$.

Comparison of the values in the subjects, taking into account the groups selected by the Pignet index, showed that hyposthenics in both hemispheres had a statistically significant $(p<0.05)$ higher values in the group of agricultural workers, compared with industrial workers and the control group.

In normosthenics, significantly significant $(p<0.05)$ differences were observed only in the right hemisphere and they are associated with statistically significantly lower values of the rheographic index in the group of industrial workers, compared with the other two comparison groups.

Subjects with a hypersthenic type of body constitution are not characterized by significantly significant intergroup differences in the values of the rheographic index throughout the study.

The average blood flow rate was statistically significantly $(p<0.05)$ higher in the right hemisphere of the subjects with hyposthenic physique of persons involved in agroindustrial production compared with a similar parameter of the control group. Normosthenics have significantly lower values in the group of industrial workers compared to other groups. The left hemisphere is characterized by the presence of intergroup differences only when comparing the performance of industrial workers and the control group (significantly lower values were observed in industrial workers).

The coefficient of asymmetry of blood supply to the 
vessels of the brain was within normal limits only in the control group of subjects, regardless of the type of body constitution.

Thus, the features of cerebral blood flow revealed the largest number of intergroup differences in the group of normosthenics, which was associated with the place of work of the subjects. The study found higher values of the coefficient of asymmetry of blood supply to the vessels of the brain in the group of industrial workers compared with employees of agricultural enterprises and the control group. This difference was observed in all groups, without exception, selected by body mass index.

Analysis of the correlation coefficients of the obtained parameters of cerebral blood flow with anthropometric indicators of individuals of all groups showed that the studied control groups are characterized by the highest number of high correlations between these indicators of both hemispheres. The greatest correlations were observed between the indicators of the Pignet index in the right hemisphere with the period of pulse oscillation $(r=-0.30)$, the time of rapid $(r=-0.38)$ and maximum $(r=-0.69)$ blood filling, the time of rheowave delay $(r=-0.59)$ and rheographic index $(r=-0.38)$, in the left - with the values of time of rapid $(r=-0.42)$ and maximum ( $r=-0.32)$ blood filling, time of delay of the rheowave $(r=-0.36)$ and dichroic index $(r=-0.44)$.

\section{Discussion}

The analysis of anthropometric data in subjects exposed to chronic exposure to a complex of harmful factors of the production environment showed that in comparison with the control group there are no differences in height, body weight, chest circumference, which indicates the homogeneity of the sample. The use of the Pignet index showed that in both groups of subjects there is no significant difference of this indicator between the comparison groups.

Systematic analysis of central and peripheral hemodynamics showed that the greatest number of differences in the values of the studied parameters are observed in workers who are negatively affected by harmful factors during production, regardless of the place of work (industry or agriculture). However, the peculiarities of indicators in these groups indicate the functional nature of the identified changes that are compensatory in nature.

The highest level of correlation of the studied indicators of the cardiovascular system according to the correlation analysis was observed in persons who do not have contact with harmful environmental factors at work, while the studied from both groups of comparisons are characterized by much lower correlations in absolute terms and their number. At the same time, the largest number of significantly high correlations was observed between the studied parameters of the circulatory system and the Pignet index, which objectifies the division of the studied by this indicator for further analysis.

It should be noted that a large number of scientists who study the impact of exogenous factors on health and functionality of the body, say that the set of negative factors of production conditions is a fairly controlled value and the possibility of negative changes in workers can occur only in violation of technological process or accidents [11]. However, given the chronic impact of such conditions and a significant number of endogenous factors that can modify the impact of negative production factors, increasing the body's sensitivity to them, this issue is constantly discussed in scientific circles $[1,20]$.

In addition, the appearance of occupational diseases as the only indicator of negative changes in the human body is unacceptable, because in this case the level of "quality of life" is leveled, which is not determined only by the absence of disease [13]. Important in the context of this problem is that the functional changes caused by the studied environmental factors are often transient $[5,6,8]$, or masked by the stress of adaptive capacity [4, 19], and therefore often not detected in during professional medical examinations of employees [12]. The following data, in particular, are given in the study of cerebral blood flow in persons exposed to chronic ionizing radiation in residents of radiation-contaminated regions: background REG in this contingent does not exceed the age norm, but the performance of intellectual tasks of varying complexity elasto-tonic changes of the vascular bed and a certain level of regulatory changes in the circulatory system [25].

Further research on this topic, in our opinion, should be aimed at studying the features of the cardio-respiratory system of persons affected by negative factors, taking into account the type of their physique during functional tests, because the changes we noted from the cardiovascular system are physiological in nature and in conditions of functional rest may not be fully manifested.

\section{Conclusions}

1. Anthropometric study of persons exposed to chronic exposure to harmful factors of production, showed no significant changes in both the group involved in industrial production and in agriculture.

2. According to the indicators of the Pignet index, the predominance of the normosthenic type of physique was revealed in all subjects, regardless of the peculiarities of the influence of harmful factors.

3. The study of central blood flow in subjects, taking into account the type of body constitution showed that in the group of hypersthenics who are employees of an industrial enterprise, there is an increase in stroke and minute blood volumes, as well as a decrease in peripheral resistance. In the group of normosthenics there are differences in the indicators of myocardial power and specific peripheral resistance in comparison with the control group of subjects.

4. In the group of hypostenics there was a significantly lower value of the period of pulse oscillation and rheographic index compared to other study groups. In hypersthenics patients, significant differences were 
observed for indicators of rapid filling time, rheographic and dichroic indices. In normosthenics, most of the differences are observed for the parameters of the right hemisphere of persons working in industrial production,

\section{References}

[1] Andjelkovic, M., Buha Djordjevic, A., Antonijevic, E., Antonijevic B., Stanic, M., Kotur-Stevuljevic, J. ... Bulat, Z. (2019). Toxic Effect of Acute Cadmium and Lead Exposure in Rat Blood, Liver, and Kidney. International Journal of Environmental Research and Public Health, 16(2), 274. https://doi.org/ 10.3390/ijerph16020274

[2] Argacha, J.F., Bourdrel, T., \& van de Borne, P. (2018). Ecology of the cardiovascular system: A focus on air-related environmental factors. Trends in Cardiovascular Medicine, 28(2), 112-126. https://doi.org/10.1016/j.tcm.2017.07.013

[3] Baldi, I., Robert, C., Piantoni, F., Tual, S., Bouvier, G., Lebailly, P., \& Raherison, C. (2014). Agricultural exposure and asthma risk in the AGRICAN French cohort. International Journal of Hygiene and Environmental Health, 217(4-5), 435-442. doi: 10.1016/j.ijheh.2013.08.006

[4] Baumgartner, J., Brauer, M., \& Ezzati, M. (2020). The role of cities in reducing the cardiovascular impacts of environmental pollution in low- and middle-income countries. BMC Medicine, 18(1), 39. https://doi.org/10.1186/s12916-020-1499-y

[5] Bourdrel, T., Bind, M.A., Bejot, Y., Morel, O., \& Argacha, J.F. (2017). Cardiovascular effects of air pollution. Archives of Cardiovascular Diseases, 110(11), 634-642. https://doi.org/ 10.1016/j.acvd.2017.05.003

[6] Brook, R.D. (2017). The Environment and Blood Pressure. Cardiology Clinics, 35(2), 213-221. https://doi.org/10.1016/ j.ccl.2016.12.003.

[7] Bunak, V.V. (1941). Антропометрия [Anthropometry]. Москва: Наркомат РСФСР - Moscow: People's Commissariat of the RSFSR.

[8] Byrd, J.B., Bard, R.L., Das, R., Wang, L., Sun, Z., Spino, C. ... Brook, R.D. (2016). Acute increase in blood pressure during inhalation of coarse particulate matter air pollution from an urban location. Journal of the American Society of Hypertension, 10(2), 133-139. https://doi.org/10.1016/ j.jash.2015.11.015

[9] Crinnion, W.J. (2012). Do environmental toxicants contribute to allergy and asthma? Alternative medicine review: A Journal of Clinical Therapeutic, 17(1), 6-18.

[10] Dmytrotsa, O., Yanko, N., Shvayko, S., Poruchynskiy, A., \& Zhuravlov, O. (2018). Indices of Oxygen Saturation in Urban and Rural Children. Biomedical Journal of Scientific \& Technical Research, 4(3), 3961-3962. doi: 10.26717/ BJSTR.2018.04.001061

[11] Dudar, T., Vitko, V., \& Kovalenko, G. (2020). Пилове забруднення та оцінка дозових навантажень від відвалів урановидобування [Dust pollution and assessment of radiation dose from uranium dumps]. Екологічна безпека та збалансоване ресурсокористування - Ecological Safety and Balanced Use of Resources, 1(21), 49-56. https://doi.org/ 10.31471/2415-3184-2020-1(21)-49-56

[12] Gorr, M.W., Falvo, M.J., \& Wold, L.E. (2017). Air Pollution and Other Environmental Modulators of Cardiac Function. Comprehensive Physiology, 7(4), 1479-1495. https://doi.org/ 10.1002/cphy.c170017

[13] Griffiths, P.E., \& Matthewson, J. (2020). Diseases are Not Adaptations and Neither are Their Causes: A Response to Ardern's "Dysfunction, Disease, and the Limits of Selection". compared with other study groups in terms of fast filling time, rheowave delay time, rheographic index and average blood flow velocity.

Biological Theory, 15, 136-142. doi: 10.1007/s13752-02000350-x

[14] Hernandez, A.F., Parron, T., \& Alarcon, R. (2011). Pesticides and asthma. Current Opinion in Allergy and Clinical Immunology, 11(2), 90-96. https://doi.org/10.1097/ ACl.0b013e3283445939

[15] Hrebniak, M.P., \& Fedorchenko, R.A. (2019). Вплив індустріальних атмосферних забруднень на розвиток патології органів дихання [Influence of industrial atmospheric pollution on the development of pathology of respiratory organs]. Пaтологія - Pathology, 16(1), 81-86. https://doi.org/10.14739/ 2310-1237.2019.1.166314

[16] Klimov, N.lu., Vinnik, lu.lu., Andreichikov, A.V., \& Maksimov, A.S. (2018). Конституциональный подход в изучении болезней человека на современном этапе [Constitutional approach to the study of human diseases at the present stage]. Сеченовский вестник - Sechenov Bulletin, 4, 70-77. doi: 10.47093/22187332.2018.4.70-77

[17] Kogan, M.P., Filimonova, E.E., \& Sorokin, E.L. (2019). Типы конституции человека и их значение в клинической прктике (обзор литературы) [Types of human constitution and their significance in clinical practice (literature review)]. Coвременные технологии в офтальмологии - Modern Technologies in Ophthalmology, 2, 229-234. doi: 10.25276/ 2312-4911-2019-2-229-234

[18] Kotysheva, E. N., Dzjundzja N. A., \& Bolotskaja M. Ju. (2008). Анализ антропометрических показателей физического развития детей 5-7 лет в условиях промышленного города [Analysis of anthropometric indicators of physical development of children 5-7 years old in an industrial city]. Педиатрия - Pediatry, 87 (2), 140-143.

[19] Lederer, A.M., Fredriksen, P.M., Nkeh-Chungag, B.N., Everson, F., Strijdom, H., De Boever, P., \& Goswami, N. (2021). Cardiovascular effects of air pollution: current evidence from animal and human studies. American Journal of Physiology. Heart and Circulatory Physiology, 320(4), H1417-H1439. https://doi.org/10.1152/ajpheart.00706.2020

[20] Newby, D.E., Mannucci, P.M., Tell, G.S., Baccarelli, A.A., Brook, R.D., Donaldson, K. ... Storey, R.F. (2015). Expert position paper on air pollution and cardiovascular disease. European Heart Journal, 36(2), 83-93b. https://doi.org/10.1093/eurheartj/ ehu458

[21] Nikolenko, V.N., Nikitiuk, D.B., \& Klochkova, C.V. (2017). Coматическая конституция и клиническая медицина [Somatic Constitution and Clinical Medicine]. Общество с ограниченной ответственностью Издательский дом Практическая медицина - Limited Liability Company Publishing House Practical Medicine.

[22] Payan-Renteria, R., Garibay-Chavez, G., Rangel-Ascencio, R., Preciado-Martinez, V., Munoz-Islas, L., Beltran-Miranda, C. ... De Celis, R. (2012). Effect of chronic pesticide exposure in farm workers of a Mexico community. Archives of Environmental \& Occupational Health, 67(1), 22-30. https:// doi.org/10.1080/19338244.2011.564230

[23] Rosenbaum, D., Hilsendegen, P., Thomas, M., Haeussinger, F.B., Metzger, F.G. ... Ehlis, A.-C. (2018). Cortical hemodynamic changes during the Trier Social Stress Test: An fNIRS study. 
Neurolmage, 171, 107-115. https://doi.org/10.1016/ j.neuroimage.2017.12.061

[24] Vlasenko, N.Y., \& Makarova, I.I. (2018). Особенности центральной гемодинамики и параметров эритроцитов при воздействии экстремальных профессиональных факторов [Peculiarities of central hemodynamics and parameters of erythrocytes under exposure to extreme professional factors]. Экология человека - Human Ecology, 8, 4-10. doi: 10.33396/1728-0869-2018-8-4-10
[25] Zhuravlov, O., Shvaiko, S., Dmytrotsa, O., \& Burban, L. (2016). Особливості реакцій серцево-судинної системи на дію іонізуючого випромінювання [The Pecurliarities of Cardiovascular System's Reactions on the Effects of lonizing Radiation]. Науковий вісник Східноєвропейського національного університету імені Лесі Українки. Біологічні науки - Scientific Bulletin of the Lesia Ukrainka East European National University. Biological sciences, 7, 184-193.

\section{ОСОБЛИВОСТІ ПОКАЗНИКІВ СЕРЦЕВО-СУДИННОЇ СИСТЕМИ В ОСІБ ЗРІЛОГО ВІКУ ЗАЛЕЖНО ВІД КОНСТИТУЦІЇ ТІЛА ЗА} НЕСПРИЯТЛИВИХ ЕКОЛОГІЧНИХ УМОВ

Шевчук Т.Я., Пшибельський В.В. Журавльов О.А., Журавльова О.В.

Здоров'я людини та її оптимальний фрункціональний стан залежать від ефективності роботи регуляторних систем організму, які реагують на зміни комплексу екзо- та ендогенних чинників, забезпечуючи своєчасну адаптацію до зміни умов існування. Однак, природні фрактори, які значною мірою визначали напрям еволюції організму людини, на сьогодні все частіше відходять на другий план, поступаючись антропогенним чинникам, зокрема умовам праці. Саме тому метою наукової статті стало вивчення стану кардіо-респіраторної системи у працівників, які задіяні у різних виробничих процесах, залежно від їх конституціі тіла. Дослідження показників центральної та мозкової гемодинаміки проводили у чоловіків віком 21-35 років (усього 90 осіб), які були поділені на 3 рівні групи: задіяні в промисловому виробництві, працівники сільськогосподарських виробництв та жителі відносно екологічно чистих районів Волинської області. На першому етапі дослідження були виміряні абсолютні антропометричні показники (зріст, маса, окружність грудної клітки) та розрахований інтегральний показник (індекс Піньє). Наступний етап дослідження передбачав проведення функціональної діагностики серцево-судинної системи досліджуваних з використанням функціональних методик ЕКГ, реографії за Кубічеком та реоенцефралографії. Реєстрацію та аналіз відповідних показників здійснювали за допомогою комплексу апаратних і програмних методів обстеження "Аскольд" (Київ, 1997). Cтатистичний аналіз міжгрупових відмінностей показників здійснювали за допомогою критерію Мана-Уітні, рівень взаємозв'язку між окремими параметрами оцінювали за методом Пірсона. Доведено, що антропометричні показники осіб, що піддаються хронічному впливу шкідливих виробничих чинників, не відрізняються як у групі осіб, задіяних у промисловому виробництві, так і в сільському господарстві. Показано, що у досліджуваних, які тривалий час зазнають впливу негативних чинників виробничого середовища (як під час виробництва сільськогосподарської продукції, так і в умовах промислового підприємства) спостерігаються компенсаторні зміни показників центральної гемодинаміки (ударного об'єму крові та потужності міокарда) порівняно з контрольною групою осіб з екологічно чистих районів Волинської області. У працівників промислового підприємства відмічені ознаки погіршення амплітудно-часових характеристик мозкового кровотоку обох півкуль, про що свідчать показники часу швидкого наповнення, реографічного коефріцієнта та середньої швидкості кровотоку. Ці параметри відрізняються від аналогічних параметрів як працівників сільськогосподарського виробництва, так і жителів відносно екологічно чистих регіонів. Таким чином, виявлені особливості показників у групах досліджуваних, що зазнають хронічного впливу негативних фракторів виробничого середовища, свідчать про фрункціональний характер виявлених змін, що носять компенсаторний характер.

Ключові слова: фактори виробничого середовища, центральна гемодинаміка, мозкова гемодинаміка, ЕКГ, антропометричні показники. 